Созонюк Ольга

кандидат психологічних наук, доцент кафедри вікової та педагогічної психології Рівненського державного гуманітарного університету http://orcid.org/0000-0002-6810-6341 DOI https://doi.org/10.35619/praprv.v1i15.196

\title{
ОСОБИСТІСНА ЗРІЛІСТЬ МАЙБУТНІХ ВЧИТЕЛІВ ЯК МЕХАНІЗМ ФОРМУВАННЯ ЇХ ПРОФЕСІЙНОЇ ІДЕНТИЧНОСТІ
}

Анотація. Стаття присвячена психологічному аналізу особистісної зрілості як необхідної умови успішного розвитку професійної ідентичності та становлення вчителя. Особистісна зрілість майбутнього вчителя є комплексною характеристикою особистості майбутнього спеціаліста, щзо забезпечує свідоме прийняття здобувачем вищої освіти професійно значущих иінностей та його прагнення реалізувати себе у процесі професійної підготовки. Особистісна зрілість майбутнього фахівия є результатом засвоєння сочіальнокультурних норм в умовах творчої взаємодії викладачів і студентів у навчально-виховному процесі вищої школи та виступає у майбутньому фактором професійного становлення особистості. Формування особистісної зрілості $\epsilon$ важливим механізмом розвитку професійної ідентичності майбутніх учителів, а саме таких ї̈ структурних компонентів як Я-концепція, мотивачія досягнення та здатність до психологічної близькості з іншими людьми.

Ключові слова: особистісна зрілість, професійна ідентичність, професійне самовизначення, професійна компетентність.

Постановка проблеми. Сучасна епоха характеризується високим ступенем динамізму та невизначеності, які обумовлюють всі сфери суспільного життя та проявляються на різних його рівнях. Ці принципово нові умови існування особистості висувають інші вимоги до підготовки та професійної освіти, які покликані формувати освіченого, ініціативного, мобільного на ринку праці, психологічно готового до виконання професійної діяльності фахівця.

Однією із необхідних умов гармонійного розвитку особистості, ऑiі творчої спрямованості та продуктивності, активного включення в соціальне життя країни $\epsilon$ становлення їі ідентичності. Ідентичність - ядро, що забезпечує постійність особистості при змінах у навколишньому світі та при зміні власних поглядів, установок і можливостей.

Аналіз останніх досліджень 3 проблеми. У психологічній науці проблема професійної ідентичності $є$ досить важливою. Актуальність ії зумовлена як розробкою теоретичних питань змісту, структури, так і іï практичним значенням, насамперед, пов'язаним із проблемами ефективності трудової діяльності, професійної адаптації, професійного навчання та професійного розвитку в цілому. Проблемі ідентичності присвячені роботи багатьох вітчизняних (Антонової, Бєлінської, Буякас, Гнатенко, Костюка, Павелківа, Рубінштейна) та зарубіжних (Адлера, Бернса, Дойса, Еріксона, Роджерса).

Метою статті є вивчення особистісної зрілості майбутніх вчителів як механізму формування їх професійної ідентичності.

Виклад основного матеріалу дослідження. Головною та неодмінною умовою успішного розвитку професійної ідентичності та становлення вчителя виступає особистісна зрілість. Всебічний гармонійний розвиток і виховання підростаючого покоління - не лише завдання, а й обов'язкова умова побудови гуманного демократичного суспільства. Вирішення цього загального завдання тісно пов'язане з реалізацією Державної програми «Освіта» (Україна XXI століття), Національної доктрини розвитку освіти України в XXI столітті, Концепції «Нова українська школа», оскільки одне з провідних місць у формуванні дитячої особистості, майбутнього громадянина належить школі. Тому здійснення шкільного 
навчально- виховного процесу вимагає висококваліфікованих вчителів-професіоналів, здатних високоякісно виконувати свої функції. Щоб формувати особистість свого учня, педагог перш за все повинен бути сам зрілою особистістю, яка володіє високою загальною і психологічною культурою, має глибоку психолого-педагогічну підготовку.

В якості однієї із провідних характеристик особистості майбутнього вчителя, що забезпечує його професійне зростання та успішність як спеціаліста, ми вбачаємо високий рівень розвитку особистісної зрілості, яка характеризується активною участю у житті суспільства, розвиненим почуттям відповідальності, потребою у піклуванні про інших людей, здатністю до ефективного використання своїх знань та здібностей, до психологічної близькості з іншою людиною, до конструктивного вирішення різних життєвих проблем на шляху до найповнішої самореалізації, i $є$ складним психологічним утворенням, до визначення структурних компонентів якого існують різні підходи.

Зауважимо, що проблему особистісної зрілості в психологічній науці розглядали й вирішували з позиції особистісно-діяльнісного підходу, основи якого були закладені в доробках Каптєрєва, Виготського, Леонтьєва, Рубінштейна, Ананьєва, Давидова, Ельконіна та ін., де особистість розглядалась як суб'єкт діяльності, яка сама, формуючись у діяльності та спілкуванні з іншими людьми, визначає характер цієї діяльності. Характеристика людини як суб'єкта розкриває спосіб організації особистістю свого життя. Людина як суб'єкт, на думку Брушлінського, ініціює та розвиває на вищому рівні системності свою специфічну активність. Цей рівень характеризується цілісністю, інтегральністю всіх суперечливих і багатоманітних компонентів і підрівнів. Такий рівень суб'єктності може бути розглянутий як вищий ступінь розвитку зрілості особистості, що $є$ одним з компонентів зрілості людини (Брушлінський, 1996). На погляд інших дослідників особистісна зрілість людини характеризується потребою виходити за існуючи межі свого життя та вирішувати проблеми вдосконалення і розвитку як свого суспільства, так і всього людства. Людину характеризує психологічне здоров'я, можливість більш повного самовираження та саморозкриття, продуктивності та творчості (Портнова, 2014).

Підкреслимо, що переважна більшість учених (Маслоу, Олпорт, Фрейд, Фромм, Еріксон та ін.) пов'язують особистісну зрілість зі здібністю людини до самостійності в судженнях і вчинках, саморегуляції, ціннісним переживанням, співпрацюванням 3 іншими, 3 відповідальністю за себе й інших у соціальній ситуації в цілому, із толерантністю й емпатією. Так, Кравець особистісну зрілість майбутнього вчителя визначає як комплексну характеристику особистості майбутнього спеціаліста, що забезпечує свідоме прийняття студентом професійно значущих цінностей та його прагнення реалізувати себе у процесі професійної підготовки. Особистісна зрілість майбутнього спеціаліста $\epsilon$ результатом засвоєння соціально-культурних норм в умовах творчої взаємодії викладачів і студентів у навчально-виховному процесі вищої школи i виступає у майбутньому фактором професійного становлення особистості (Кравець, 2005).

Критеріями особистісної зрілості майбутнього вчителя автор називає: автономність (самостійність у судженнях та вчинках); відповідальність за результати навчальнопрофесійної діяльності; здатність до співробітництва та взаєморозуміння з однокурсниками та викладачами на основі толерантності та емпатії; здатність до саморегуляції індивідуальних станів (Кравець, 2005).

Гільбух основними структурними компонентами особистісної зрілості вважає:

мотивацію досягнення (загальна спрямованість діяльності індивіда на значущі життєві цілі, прагнення до максимально повної самореалізації, самостійність, ініціативність, прагнення до лідерства, досягнення високих результатів);

ставлення до свого Я (Я-концепція) (впевненість у своїх можливостях, задоволення своїми здібностями, темпераментом і характером, своїми знаннями, уміннями $\mathrm{i}$ навичками, адекватна самооцінка, висока вимогливість до себе);

почуття громадянського обов'язку (патріотизм, інтерес до суспільнополітичного життя, почуття професійної відповідальності, потреба у спілкуванні); 
- життєву установку (розуміння відносності сенсу життя, переважання раціонального над емоційним, емоційна врівноваженість, розсудливість);

здатність до психологічної близькості з іншими людьми (доброзичливість до людей, емпатія, уміння слухати, потреба у спілкуванні з однодумцями, довіра до себе та довіра до оточення) (Гільбух, 1994).

Особистісна зрілість, як зазначає Чорний, характеризується відчуттям ідентичності. Відчуття ідентичності, на думку дослідника, це один із важливих показників особистісної зрілості (Чорний, 2000). Так, Реан виділяє чотири базові компоненти особистісної зрілості: відповідальність, терпимість, саморозвиток і четвертий, базовий - інтегральний компонент позитивне мислення (Реан, 2007). Критерії зрілості особистості виділяються у таких категоріях: 1) категорія внутрішніх компонентів зрілості, що включає в себе індивідуальні якості особистості: психічна автономія, пам'ять, емоційна зрілість, інтерналізація цінностей, інтерналізація норм, вразливість, темперамент, зовнішність, домагання, адекватна оцінка та самооцінка; 2) категорія зовнішніх компонентів зрілості, що включає в себе суспільні якості особистості: інтерперсональна компетенція; просуспільна діяльність, відкритість, емпатія, інтерперсональна близькість, гармонія 3 оточуючим середовищем, автономний погляд на світ. При цьому автори підкреслюють, що виділені ними компоненти зрілості особистості взаємообумовлені та взаємодіють.

Потапчук у якості структурних компонентів особистісної зрілості виділяє: відповідальність у різних сферах життєдіяльності, емоційну зрілість, самоконтроль поведінки, самостійність, адекватність самоствердження, цілепокладання, високий рівень реалізованості подій життя (Потапчук, 2001). Зрілу особистість, на думку Штепи, визначають: синергічність, автономність, контактність, самоприйняття, креативність, толерантність, відповідальність, глибинність переживань, здатність до децентрації та наявність власної життєвої філософії (Штепа, 2005). Гільбух структурними компонентами особистісної зрілості вважає: мотивацію досягнення; ставлення до свого Я (Я-концепція); почуття громадянського обов'язку; життєву установку; здатність до психологічної близькості 3 іншими людьми (Гільбух, 1994). Мотивація досягнення - загальна спрямованість діяльності індивіда на значущі життєві цілі, прагнення до максимально повної самореалізації, самостійність, ініціативність, прагнення до лідерства, досягнення високих результатів. Ставлення до свого Я (Я-концепція) включає такі характеристиками зрілості як впевненість у своїх можливостях, задоволення своїми здібностями, темпераментом i характером, своїми знаннями, уміннями і навичками. Разом із тим даний аспект передбачає такий суттєвий параметр поведінки як адекватна самооцінка, висока вимогливість до себе, відсутність самовдоволення, скромність, повага до інших людей. 3 почуттям громадянського обов'язку Гільбух пов'язує, перш за все, такі якості як патріотизм, інтерес до суспільнополітичного життя, почуття професійної відповідальності, потреба у спілкуванні, колективізм. Життєва установка поєднує такі якості як розуміння відносності сенсу життя, переважання раціонального над емоційним, емоційна врівноваженість, розсудливість. У поняття здатність до психологічної близькості з іншими людьми включені такі особистісні якості як доброзичливість до людей, емпатія, уміння слухати, потреба в духовній близькості 3 іншими людьми. Загалом, феномен особистісної зрілості та окремі ії компоненти були предметом психологічних досліджень, однак становлення цього феномену в процесі професійної підготовки та його специфіка стосовно вчительської професії не вивчались.

Аналіз досліджень, що безпосередньо торкаються структурних компонентів особистісної зрілості показує, що майже всі дослідники включають такі компоненти як відповідальність у різних сферах життєдіяльності, позитивне ставлення до себе, терпимість, встановлення глибоких контактів 3 людьми, потребу у саморозвитку, прагнення до максимально повної самореалізації, наявність власної життєвої філософії. 3 огляду на це, нам найбільше імпонує структура особистісної зрілості Гільбуха, який в якості компонентів особистісної зрілості виділяе, як уже зазначалось, мотивацію досягнення, цілісну Яконцепцію, почуття громадянського обов'язку, життєві установки, здатність до 
психологічної близькості з іншими людьми. Дана структура найбільш повно, на нашу думку, інтегрує в собі різні підходи до визначення компонентів особистісної зрілості та включає аспекти професійно-особистісного зростання майбутнього спеціаліста.

Названі положення і стали підгрунтям для нашого припущення про взаємозв'язок між професійною ідентичністю та особистісною зрілістю майбутніх учителів.

Для участі в дослідженні було залучено 65 студентів I та IV курсів Рівненського державного гуманітарного університету. Вивчення статусів професійної ідентичності проводилось за однойменною методикою Азбель, Грецової (Райгородський, 2000). Вивчення особистісної зрілості проводилося за допомогою «Тесту-опитувальника особистісної зрілості» (Гільбух, 1994).

Таблиия 1

Розподіл майбутніх учителів за статусами професійної ідентичності та рівнями особистісної зрілості

\begin{tabular}{|c|c|c|c|c|}
\hline \multirow[t]{2}{*}{ Курс } & \multirow{2}{*}{$\begin{array}{c}\text { Статус } \\
\text { професійної } \\
\text { ідентичності }\end{array}$} & \multicolumn{3}{|c|}{ Якісні і кількісні показники } \\
\hline & & $\%$ & $\begin{array}{c}\text { рівень особистісної } \\
\text { зрілості }\end{array}$ & $\%$ \\
\hline \multirow[t]{9}{*}{ I курс } & \multirow[t]{3}{*}{ сформована } & \multirow[t]{3}{*}{49,1} & дуже високий & 3,6 \\
\hline & & & високий & 14,5 \\
\hline & & & задовільний & 30,9 \\
\hline & \multirow[t]{2}{*}{ дифузія } & \multirow[t]{2}{*}{10,9} & високий & 1,8 \\
\hline & & & задовільний & 9,1 \\
\hline & \multirow[t]{2}{*}{ нав’язана } & \multirow[t]{2}{*}{5,5} & високий & 1,8 \\
\hline & & & задовільний & 3,6 \\
\hline & \multirow[t]{2}{*}{ мораторій } & \multirow[t]{2}{*}{34,5} & незадовільний & 23,6 \\
\hline & & & задовільний & 10,9 \\
\hline \multirow[t]{6}{*}{ V курс } & \multirow[t]{3}{*}{ сформована } & \multirow[t]{3}{*}{50,9} & дуже високий & 7,3 \\
\hline & & & високий & 21,8 \\
\hline & & & задовільний & 21,8 \\
\hline & \multirow[t]{2}{*}{ мораторій } & \multirow[t]{2}{*}{47,3} & незадовільний & 21,8 \\
\hline & & & задовільний & 25,5 \\
\hline & невизначена & 1,8 & задовільний & 1,8 \\
\hline
\end{tabular}

Порівняльний аналіз показників статусів професійної ідентичності та рівнів особистісної зрілості майбутніх учителів засвідчує, що у студентів першого курсу, зі статусом сформованої професійної ідентичності діагностується дуже високий $(3,6 \%)$, високий $(14,5 \%)$ та задовільний $(30,9 \%)$ рівень особистісної зрілості. У студентів першокурсників 3 нав'язаною та невизначеною професійною ідентичністю виявляється задовільний $(3,6 \%, 9,1 \%$ відповідно) та високий $(1,8 \%, 1,8 \%$ відповідно) рівні особистісної зрілості. Студенти-першокурсники, зі станом мораторію професійної ідентичності мають незадовільний $(23,6 \%)$ та задовільний $(10,9 \%)$ рівень особистісної зрілості.

Аналіз отриманих результатів демонструє, що у студентів IV курсу зі статусом сформованої професійної ідентичності діагностується дуже високий $(7,3 \%)$, високий $(21,8 \%)$ та задовільний $(21,8 \%)$ рівні особистісної зрілості. Студенти-випускники зі статусом мораторію професійної ідентичності мають незадовільний $(21,8 \%)$ та задовільний $(25,5 \%)$ рівні особистісної зрілості. Для студентів п’ятого курсу з невизначеною професійною ідентичністю характерним є задовільний рівень особистісної зрілості - 1,8\%.

Отримані дані свідчать, що у студентів IV курсу незадовільний рівень особистісної зрілості зменшується на 7,2\% та на 3,6\% порівняно 3 I курсом. А також серед студентіввипускників зростає, порівняно зі студентами I курсу, кількість студентів (на 7,3\%) із 
високим рівнем особистісної зрілості та діагностується 7,3\% студентів із дуже високим рівнем особистісної зрілості.

Проведене експериментальне дослідження дає підстави стверджувати, що життя упродовж чотирьох років навчання у вищому навчальному закладі призводить до певного підвищення показників особистісної зрілості та зміни у статусах професійної ідентичності у бік сформованої професійної ідентичності, проте отримані дані показують, що на певному етапі професійної підготовки у студентів спостерігається зниження усіх показників професійної ідентичності та особистісної зрілості, що свідчить про переоцінку цінностей, послаблену мотивацію та кризу професійної ідентичності. Водночас, показники сформованої професійної ідентичності та особистісної зрілості студентів-випускників незадовільні. Цей факт свідчить про необхідність психологічного супроводу становлення професійної ідентичності студентів педагогічних спеціальностей та розвитку їх особистісної зрілості упродовж всього навчання у вищому навчальному закладі.

Таким чином, проведене дослідження показало, що для статусу сформованої, нав'язаної та невизначеної професійної ідентичності характерний високий, задовільний та дуже високий рівні особистісної зрілості. Незадовільний та задовільний рівні особистісної зрілості діагностуються у студентів зі станом мораторію професійної ідентичності.

Висновки і перспективи подальших розвідок. Отже, важливим механізмом розвитку професійної ідентичності майбутніх учителів $є$ формування їх особистісної зрілості, а саме таких структурних компонентів особистісної зрілості майбутніх педагогів як Я-концепція, мотивація досягнення та здатність до психологічної близькості 3 іншими людьми.

\section{СПИСОК ПОСИЛАНЬ}

Брушлинский, А. В. (1996). Субъект: мышление, учение, воображение. Москва: Ин-т практ. психологии.

Гильбух, Ю. 3. (1994). Тест-опросник личностной зрелости. Киев: Науч.-практ. центр «Психодиагностика и дифференцированное обучение».

Кравец, Г. Ю. (2005). Педагогические условия проявления личностной зрелости студентов 8 учебно-воспитальном прочессе вуза. (Дис. канд. пед. наук). Иркутский государственный педагогический университет, Иркутск.

Портнова, А. (2014). Вплив особистісної і професійної зрілості спеціаліста на досягнення рівня професіоналізму. Взято з http: // konfep. narod.ru/portn.htm.

Потапчук, Л. В. (2001). Психологічні особливості становлення особистісної зрілості старшокласників. (Автореф. дис. канд. психолог. наук). Національний педагогічний університет імені М. П. Драгоманова, Київ.

Райгородский, Д. Я. (2000). Практическая психодиагностика. Методики и тесты. Москва: Бахрах-М.

Реан, А. А., \& Коломинский, Я. Л. (2007). Социальная педагогическая психология. СанктПетербург: Питер.

Черный, Е. В. (2000). Профессиональная идентичность практического психолога. Практична психологія та соиіальна робота, 8, 36-39.

Штепа, О. С. (2005). Феномен особистісної зрілості. Соціальна психологія, 1, 62-77.

\section{REFERENCES}

Brushlinskiy, A. V. (1996). Sub'ekt: myishlenie, uchenie, voobrazhenie [Subject: thinking, teaching, imagination]. Moskva: In-t prakt. psihologii. [in Russian].

Gilbuh, Yu. Z. (1994). Test-oprosnik lichnostnoy zrelosti [Personal maturity questionnaire]. Kiev: Nauch.-prakt. tsentr «Psihodiagnostika i differentsirovannoe obuchenie». [in Russian].

Kravets, G. Yu. (2005). Pedagogicheskie usloviya proyavleniya lichnostnoy zrelosti studentov $v$ uchebno-vospitalnom protsesse vuza [Pedagogical conditions of manifestation of personal maturity of students in the university educational process]. (Dis. Kand. ped. nauk). Irkutskiy gosudarstvennyiy pedagogicheskiy universitet, Irkutsk. [in Russian]. 
Portnova, A. (2014). Vplyv osobystisnoi i profesiinoi zrilosti spetsialista na dosiahnennia rivnia profesionalizmu [The influence of the specialist's personal and professional maturity on the achievement of the professionalism level]. Vziato z http: // konfep. narod.ru/portn.htm. [in Ukrainian].

Potapchuk, L. V. (2001). Psykholohichni osoblyvosti stanovlennia osobystisnoi zrilosti starshoklasnykiv [Psychological features of the formation of personal maturity of highschool students]. (Avtoref. dys. kand. psykholog. nauk). Natsionalnyi pedahohichnyi universytet imeni M. P. Drahomanova, Kyiv. [in Ukrainian].

Raygorodskiy, D. Ya. (2000). Prakticheskaya psihodiagnostika. Metodiki i testyi [Practical psychodiagnostics. Techniques and tests]. Moskva: Bahrah-M. [in Russian].

Rean, A. A., \& Kolominskiy, Ya. L. (2007). Sotsialnaya pedagogicheskaya psihologiya [Social pedagogical psychology]. Sankt-Peterburg: Piter. [in Russian].

Chernyiy, E. V. (2000). Professionalnaya identichnost prakticheskogo psihologa [Professional identity of a practical psychologist]. Praktichna psihologIya ta sotsIalna robota, 8, 36-39. [in Ukrainian].

Shtepa, O. S. (2005). Fenomen osobystisnoi zrilosti [The phenomenon of personal maturity]. Sotsialna psykholohiia, 1, 62-77. [in Ukrainian].

\title{
PERSONAL MATURITY OF FUTURE TEACHERS AS A MECHANISM OF THEIR PROFESSIONAL IDENTITY FORMATION
}

Olha Sozoniuk

Candidate of psychological sciences, Associate Professor of Age and Pedagogical Psychology at Rivne State Humanitarian University http://orcid.org/0000-0002-6810-6341 DOI https://doi.org/10.35619/praprv.v1i15.196

\begin{abstract}
The article is devoted to the psychological analysis of personal maturity as a necessary condition for the successful development of professional identity and becoming a teacher. The personal maturity of a future teacher is a complex characteristic of the future specialist's personality, which ensures that someone who gets higher education consciously accepts the professionally significant values and his desire to realize himself in the process of professional training. Personal maturity of the future teacher is the result of mastering the socio-cultural norms in the creative interaction of teachers and students in the educational process of higher education and is a future factor in the professional development of the individual. The formation of personal maturity is an important mechanism for the development of professional identity of future teachers, namely its structural components such as I-concept, achievement motivation and the ability to be psychological close to other people.

Professional identity is a psychological category that refers to the awareness of the profession of a person who belongs to a particular professional community. The professional identity of the teacher in the psychological and pedagogical literature is defined as an integral characteristic of an individual. On one hand, it can be related to social identity because it is not depleted by the adoption of appropriate professional roles and functions. On the other hand, it does not belong to the identity itself, since the attitude towards oneself as a professional is only one of the indicators of the formation of professional identity. The integrality of such a personal characteristic is that both forms of identity are represented in the structure of professional identity.

Professional identity is a necessary part of personal professional development, becoming a professional and career development. By forming a professional identity, future teachers adjust their own style of work, become aware of their professional opportunities, learn to manage their own career development, and increase their professional competence.
\end{abstract}

Key words: professional orientation, vocational and educationalorientation, professional identity, professional marginalism. 